HEALTH AND ENVIRONMENTAL CONCERNS ASSOCIATED WITH HEAVY METALS IN FISH, SHELLFISH AND CANNED GOODS AVAILABLE IN THE PHILIPPINES

Marilou Magistrado Saong. School of Natural Sciences, University of Baguio, Baguio City, Philippines

\title{
10.1136/bmjopen-2015-forum2015abstracts. 75
}

Background The well-known long term toxic effects of heavy metals to man are of both scientific and environmental concerns. With the increasing number of heavy metal contaminants being present in the environment, the health and safety of people are at risk as these toxicants can contaminate even the food that people consume. Thus, heavy metal contamination of prime commodities such as food becomes a primary concern.

Objectives This paper presents the results of heavy metal analyses in selected fish, shellfish and canned good products available in the Philippines.

Methods Samples of Tilapia fish (Oreochromis niloticus), Pernaviridis (shellfish), canned sardines and canned meat loaves were analyzed using Atomic Absorption Spectrophotometry.

Result The mean values of cadmium (Cd) in the gills, intestine and muscle tissues of tilapia collected were $0.294 \mathrm{ppm}, 0.406 \mathrm{ppm}$ and $0.333 \mathrm{ppm}$, respectively. The concentrations of $\mathrm{Cd}$ in the different parts of tilapia fish exceeded the limits of WHO and FEPA. The mean levels of cadmium in the meat of Pernaviridis from two locations in the Philippines were $0.0077 \mathrm{ppm}$ and $0.010 \mathrm{ppm}$. These values were within the tolerable limit set by WHO. There were no detectable amounts of lead from the Pernaviridis samples. The mean values of Copper in the two brands of canned sardines, and the two brands of canned meat loaves were $41.73267 \mathrm{ppm}$, $113.82633 \mathrm{ppm}, 129.71033 \mathrm{ppm}$, and $162.74533 \mathrm{ppm}$, respectively. All the values exceeded the allowable limit for Copper. The mean values of Lead in the four brands of canned sardines and meat loaves were 294.55900 ppm, 958.89233 ppm, 340.57967 ppm and $335.78400 \mathrm{ppm}$, respectively. All the values exceeded the allowable limit for Lead.

Conclusion The results of these studies suggest that it is important for the food industries in the Philippines to ensure that their products are free from heavy metal contamination. 